\title{
Assessing the Science Interest, Attitude, and Self-Efficacy of Qatari Students at the Preparatory, Secondary, and University Levels
}

\author{
Ziad Said ${ }^{1 *}$, Ahmed A. Al-Emadi ${ }^{2}$, Heather L. Friesen ${ }^{3}$, Elina Adam ${ }^{1}$ \\ ${ }^{1}$ College of the North Atlantic-Qatar, QATAR \\ ${ }^{2}$ Qatar University, QATAR \\ ${ }^{3}$ Abu Dhabi University, UNITED ARAB EMIRATES
}

Received 21 April 2018 - Revised 3 July 2018 • Accepted 18 July 2018

\begin{abstract}
A large sample ( $n=1,799)$ of Qatari female and male students at the preparatory, secondary, and university levels responded to Likert items about their interest, attitude, and self-efficacy regarding science. The items were similar to those of TIMSS and PISA, but improved upon them in several ways. The findings suggest that Qatari students are positive in their interest, attitude, and self-efficacy, but not as positive as TIMSS and PISA report. The findings raise an important question: If the students' interest, attitude, and self-efficacy are positive, then why do the students have relatively low achievement scores on TIMSS and PISA? The answer may be the instructional methods and conditions of a developing educational system. The present findings have implications for all countries that use TIMSS and PISA, particularly those countries with developing educational systems, rapidly expanding economies, and an increasing need for students in science careers.
\end{abstract}

Keywords: scientific literacy, assessment, interest, attitude, self-efficacy

\section{INTRODUCTION}

Scientific literacy is of global importance. The Programme for International Student Assessment (PISA), a worldwide study conducted by the Organisation for Economic Co-operation and Development (OECD, 2016a), defines scientific literacy as the ability to engage with science-related issues, and with the ideas of science, as a reflective citizen. The mission of the OECD is to promote policies that will improve the economic and social wellbeing of people around the world.

Scientific knowledge is an essential component of scientific literacy, but it is not the only component. Interest, attitude, and self-efficacy are essential components as well (Feinstein, 2011; Kelly, 2011; Sheldrake, Mujtaba, \& Reiss, 2017). All of these components contribute to students' scientific literacy. Scientific knowledge is in the cognitive domain of education, whereas interest, attitude, and self-efficacy are in the affective domain. High interest, a positive attitude, and strong self-efficacy can foster scientific literacy, whereas low interest, a negative attitude, and weak self-efficacy can hinder it. If students have high interest, a positive attitude, and strong selfefficacy, but low scientific knowledge, then instructional methods and conditions may be responsible for the low knowledge.

Fortus (2014) summarizes research on interest, attitude, and self-efficacy in the area of science education. Essentially, interest is a state of wanting to learn more about something or to be involved in something. It can be "individual interest," which is being engaged over time, or "situational" interest, which is momentary engagement. An attitude refers to a set of emotions, beliefs, and behaviors toward a particular object, person, thing, or event. Selfefficacy is the task-specific belief that one has the potential to learn and achieve. Interest, attitude, and self-efficacy can affect motivation, which is the process that initiates, directs, and maintains goal-oriented behaviors.

(c) 2018 by the authors; licensee Modestum Ltd., UK. This article is an open access article distributed under the terms and conditions of the Creative Commons Attribution License (http://creativecommons.org/licenses/by/4.0/). $\square$ ziad.said@cna-qatar.edu.qa (*Correspondence) $\boldsymbol{\nabla}$ ded3aga@qu.edu.qa $\boldsymbol{\square}$ heather.friesen@adu.ac.ae 


\section{Contribution of this paper to the literature}

- The present findings have implications for all countries that use TIMSS and PISA, particularly those countries with developing educational systems.

- The Likert assessment items used were similar to TIMSS and PISA items, but with improvements.

- The items in this work contained neutral mid-points in recognition of the fact that some students, particularly children, may not yet be sure of their levels of interest, attitude, and self-efficacy and forcing them to select a positive or negative response may be misleading.

Scientific literacy is important in all countries, but it is particularly important in developing countries. Many of the Arab countries are designated developing countries by the United Nations. Qatar, for example, is sometimes designated a developing country, but the label is misleading. Qatar is a "developing" country in some respects, such as education, but not in others, such as gross domestic product (GDP) per citizen. Qatar has a high GDP per citizen, as does its Arab neighbors Kuwait, Saudi Arabia, and the United Arab Emirates. These countries derive high export revenues from natural gas, oil, and the sale of other raw materials

The income differences among the people of Qatar are quite large, and the steady growth of Qatar's population (about 2.6 million), due in part to a constant influx of immigrants, is straining the capacity of Qatar's public schools and contributing to large class sizes.

Scientific literacy is important in Qatar and its Arab neighbors for the reasons it is important in all countries, but there are also unique aspects to the need for scientific literacy in Qatar. The rapidly expanding economy of Qatar, in combination with rapid social changes, is redirecting the interest of many students away from careers in science and toward careers in finance.

In recent years, the number of students graduating from Qatar public colleges and universities in the specializations of accounting, economics, and banking was many times greater than the number of students graduating in chemistry, biology, and biomedical sciences (Qatar Ministry of Development Planning and Statistics, 2018). Furthermore, some years there were no graduates in the specialization of physics, even though the specialization is available. The number of graduates in engineering was higher than the number in science, as would be expected in a fuel exporting country, but still lower than the number in finance.

Another unique aspect of scientific literacy in Qatar is gender. The number of women graduating from Qatar's public colleges and universities is much higher than the number of men. For example, 2,236 women and 528 men graduated from Qatar's largest public university, Qatar University, in academic year 2015-16. This disparity seems strange because the population of Qatar consists of 697,899 females and 2,034,011 males (Ministry of Development Planning and Statistics, 2018). These figures represent the number of all people (citizens and non-citizen residents) within Qatar. Again, the constant influx of immigrants, particularly males - for work and the potential of a better life-contributes to gender imbalances and the complexity of Qatar society. This complexity poses strong challenges to developing the scientific literacy of all Qataris, citizens and non-citizen residents.

Data regarding the number of Qatar University women and men graduating in science specializations are not available, but they are available for engineering, where the number of women and the number of men earning B.Sc. degrees were similar in recent years. Although women and men engineering graduates are similar in numbers, keep in mind that there are four times as many women graduating from Qatar University than men, so in a real sense, women are underrepresented in engineering and, most likely, in science.

Scientific knowledge is an essential component of scientific literacy, and one indicator of scientific knowledge is the science score on TIMSS (Trends in International Mathematics and Science Study). This test is managed by the International Association for the Evaluation of Educational Achievement (IEA) and administered internationally to students in grade four (about 10 years of age) and eight (about 14 years of age). In TIMSS 2015, students in Singapore scored at the top (Martin, Mullis, Foy, \& Hooper 2016). Qatari students did not do well. Qatari fourth graders placed in the bottom one-quarter of 47 educational systems assessed worldwide. Qatari eighth graders placed in the bottom one-third of 39 systems assessed worldwide (see Figure 1). Although both female and male Qatari students scored relatively low, the females scored significantly higher than the males in both the fourth and eighth grades. 


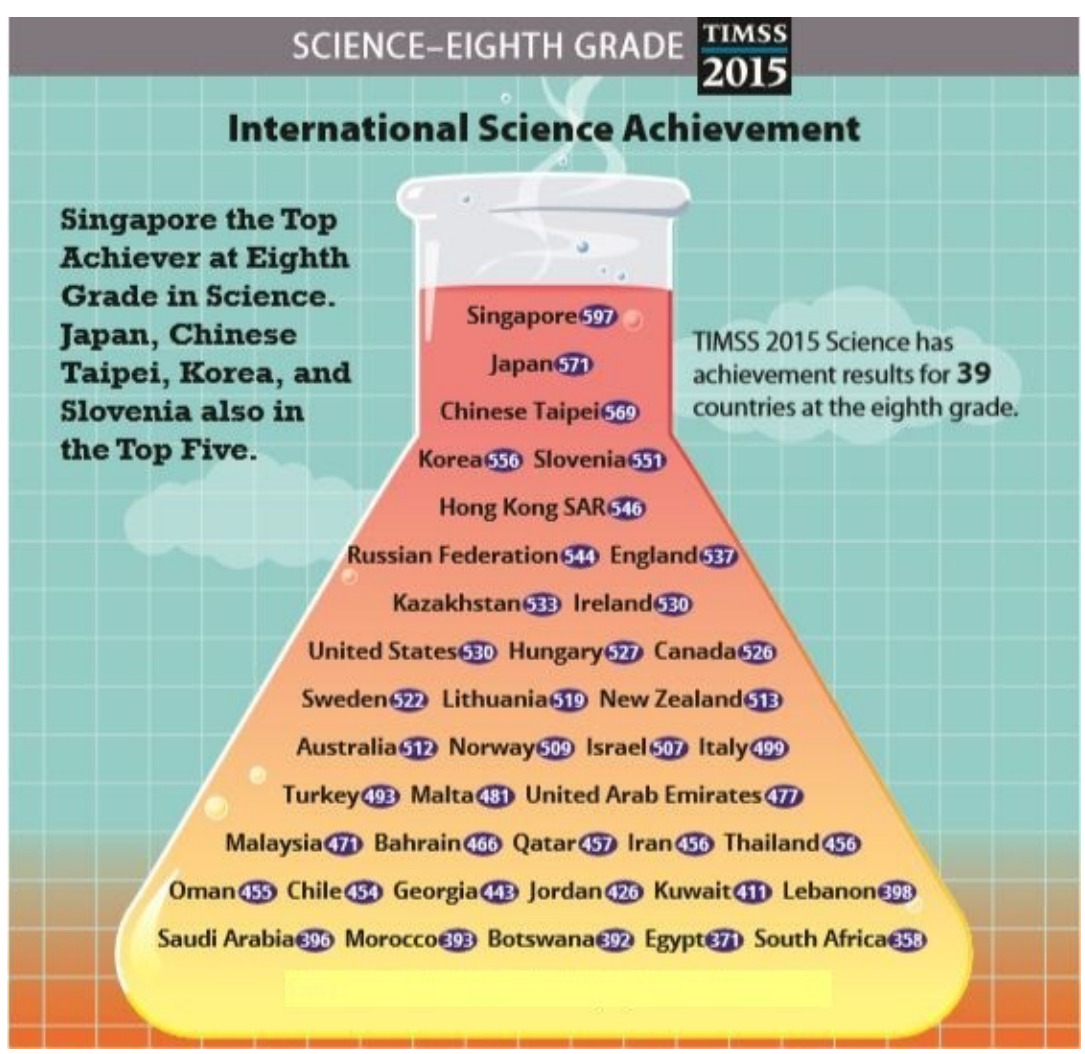

Figure 1. TIMSS (2015) eighth-grade international science achievement scores

Source: Mullis, I. V. S., Martin, M. O., \& Loveless, T. (2016). 20 Years of TIMSS: International Trends in Mathematics and Science Achievement, Curriculum, and Instruction. Chestnut Hill, MA: TIMSS \& PIRLS International Study Center, Boston College. Retrieved from http://timss2015.org/timss2015/wp-content/uploads/2016/T15-20-years-of-TIMSS.pdf

Another indicator of scientific knowledge is the science score on the PISA (Programme for International Student Assessment). This test is managed by the Organisation for Economic Cooperation and Development (OECD, 2018a) and administered internationally to students who are about 15 years of age in secondary schools. In PISA 2015, Singapore again scored at the top. Qatari students did not do well, scoring in the bottom one-quarter of the 70 systems assessed worldwide. Although both female and male Qatari students scored relatively low, the females scored significantly higher than the males. Regarding Qatar, PISA noted "the difference between boys and girls in science performance is one of the largest among PISA-participating countries and economies in favour of girls" (OECD, 2018b). PISA also noted that although Qatar's scores remain relatively low, Qatar is one of only six countries in which scores have significantly improved in recent test cycles.

Interest, attitude, and self-efficacy are essential components of scientific literacy. In addition to achievement data, TIMSS collects contextual data about the conditions in which participating students learn. In TIMSS 2015, Qatari students scored higher than students did in most of the educational systems worldwide on the scale "students like learning science" (Martin, Mullis, Foy, \& Hooper 2016). In fact, according to TIMSS, 60\% of Qatari fourth graders "very much like learning science," $31 \%$ "like learning science," and only 9\% "did not like learning science." The percentages fell for eighth graders but were still relatively high: $38 \%$ "very much like learning science" and $43 \%$ "like learning science"; only 19\% did not like learning science. The findings were similar for Qatari fourth and eighth graders on the TIMSS "students' value science" and "students' confident in science" scales.

The validity of the TIMSS assessment of Qatari students' liking, valuing, and confidence with respect to science is questionable, however, because of a limitation of the item format TIMSS uses. The TIMSS item has no mid-point (neutral point) on its scale, with a response option such as "don't know," "unsure," or "uncertain." Here is a typical TIMSS item:

How much do you agree with this statement about science?

I am just not good at science.

_ agree a lot_agree a little__disagree a little_disagree a lot 
Ideally, a Likert-item has a format like this:

How much do you agree with this statement about science?

I am interested in science.

_ agree a lot__agree a little _ don't know _ disagree a little _ disagree a lot

A mid-point (neutral point) on a scale (an ordinal scale, which is assumed to be interval) is important from both statistical and psychological perspectives (Allen \& Seaman, 2007). On the topic of rating scales, Nowlis, Kahn, and Dhar (2002, p. 332) concluded "our data clearly demonstrate ways in which consumer responses can be significantly altered by excluding a neutral position when respondents are ambivalent....The attitudes towards most objects involve some sort of mixed feelings on the part of the respondents."

The lack of a neutral point forces children to pick an option either on the lower or higher end of the rating scale. In reality, some children may be legitimately neutral in their opinion. Forcing some children to respond to an item without a neutral point may bias the survey findings because the responses may not be truly representative of what the children think. TIMSS was first conducted in 1995, and it has been administered in a cycle every four years since. TIMSS likely retains the same format (no neutral point) it has used in previous administrations so that it can compare children's responses over time. But those responses may not be entirely representative of what children think. Qatari children may in fact have less (or more) interest, attitude, and self-efficacy regarding science than TIMSS concluded. Without a neutral point on the rating scales, the responses are less exact.

Like TIMSS, PISA collects contextual data about the conditions in which participating secondary students learn. PISA reports that on its "index of enjoyment of learning science" Qatari secondary students score significantly above the international average (OECD, 2016b). As is the case with TIMSS, the validity of the PISA assessment of Qatari students' enjoyment of learning science is questionable because the PISA item format lacks a neutral point. Here is a typical PISA item:

How much do you disagree or agree with the statements about yourself below?

I am interested in learning about science.

_ strongly disagree __disagree _agree _ strongly disagree

PISA was first conducted in 2000, and PISA, like TIMSS, wants to compare students' responses over time and, to do so, it must reuse its item-response format without a neutral point.

A large sample of female and male preparatory, secondary, and university students participated in the present study. One purpose of the present study was to assess independently the interest, attitude, and self-efficacy that Qatari students have regarding their learning of science. This is important because the rapidly expanding economy of Qatar, in combination with rapid social changes, appears to be directing the interest of many students away from careers in science and toward careers in finance. A related purpose was to assess the intent of these female and male Qatari students to pursue careers in science. The items were similar to TIMSS and PISA items, but with improvements, consistent with item guidelines in the affective domain (Miller, Linn, \& Gronlund, 2013; Popham, 2014). For example, the surveys administered to these students used Likert items that contained neutral mid-points in recognition of the fact that some students, particularly young children, may not yet be sure of their levels of interest, attitude, and self-efficacy in the area of science.

\section{METHOD}

\section{Participants}

The participants in this study included 1,799 students (1,059 females and 740 males). There were 624 students from Qatari preparatory schools (from Grades 7, 8, and 9), 435 students from Qatari secondary schools (Grades 10, 11, and 12), and 740 students from six Qatari universities. The participating universities and colleges were the Carnegie Mellon University-Qatar, College of the North Atlantic-Qatar, Community College-Qatar, Qatar University, Texas A \& M -University Qatar, and Weil Cornell-Qatar. These six institutions offer science programs (biology, medical and engineering programs) and programs in other areas such as business, finance, art, and humanities.

The sampling was guided by the population statistics of Qatari students reported in "Education in Qatar Statistical Profile 2016" (Qatar Ministry of Development Planning and Statistics, 2017). The students' participation was informed and voluntary, rather than compulsory, consistent with the policies of the schools and universities. 
As noted previously, females are more numerous than males in Qatari schools and universities, and females voluntarily participated in greater numbers than males, which is frequent in educational research.

The students volunteered to "to help provide a better understanding the interests and attitudes of students learning science."

\section{Questionnaire}

In earlier studies (Abd-El-Khalick, Summers, Said, Wang, \& Culbertson, 2015; Said, 2016; Said, Summers, AbdEl-Khalick, \& Wang, 2016), a pool of Likert-type items were developed to assess aspects of Arabic-speaking students learning science. In response to a variety of items in the affective domain, students responded on a 5-point scale: strongly agree, agree, don't know, disagree, strongly disagree. The theories of reasoned action and planned behavior developed by Ajzen and Fishbein (2005) guided item development, as did systematic reviews of the research literature on student attitudes toward science (e.g., Osborne et al., 2003).

First, in the item development process, a 10-member expert panel of university and school science educators, who were fluent in both spoken and written Modern Standard Arabic (MSA) and English, examined the items for content validity, comprehensibility, and comparability. There were MSA and English versions of the items. Backward translation was used to ensure the equivalency of the two versions. The items were revised and consolidated into a 60-item set. This set was piloted with 369 Qatari school students. Some students completed an Arabic version of the instrument and some completed an English version to ensure comparability of versions.

Representative students were interviewed and asked to comment on the item set (as a whole) and on individual items. A revision was then administered to a national sample of 3,027 students from preparatory and secondary schools. The student comments were used to improve the items. Item analyses indicated that subsets of items were associated with interest and attitude (feeling) toward science and school science, unfavorable outlook on science, self-efficacy (control belief) about science, behavioral belief about science, and intentions to pursue science. This $60-$ item set was intended to provide a pool for smaller subsets of items to be used for specific purposes in subsequent studies, such as the present one.

The purpose of the present study was to assess students' interest, attitude, and self-efficacy with respect to science: 22 items were selected for this purpose from those developed in the earlier study. The items included interest items (e.g., I do interesting activities in science classes), attitude items (e.g., I enjoy science), and self-efficacy items (e.g., I am confident that I can understand science). The items were similar to TIMSS and PISA items, but with three improvements, consistent with item guidelines in the affective domain (Miller, Linn, \& Gronlund, 2013; Popham, 2014). First, the items in the present study used a 5-point Likert scale response format that contained a neutral mid-point in recognition of the fact that some students, particularly children, may not yet be sure of their levels of interest, attitude, and self-efficacy in the area of science. Second, the items were succinct because relatively long items can be confusing to children. And third, the items were positively worded because negatively worded items can be confusing to children. For example, a negatively worded self-efficacy TIMSS item that could be confusing to children was:

$$
\begin{aligned}
& \text { How much do you agree with this statement about science? } \\
& \text { "Science is harder for me than for many of my classmates." } \\
& \text { _ agree a lot_agree__disagree a little__disagree a lot } \\
& \text { In the present study, a typical positively worded self-efficacy item was: } \\
& \text { How much do you agree with this statement about science? } \\
& \text { "I am sure I can do well in science tests." } \\
& \text { _ strongly agree _ agree__don't know__disagree_ strongly disagree }
\end{aligned}
$$

\section{Procedures}

The participating students responded to the items in their classrooms under the supervision of their regular classroom teacher and study research assistants. The research assistants followed a scripted, standard protocol for introducing the study, first obtaining informed consent and explaining associated assurances, giving instructions to complete the instrument, and monitoring students as they answered items by marking their responses. In the case of preparatory school students, the study research assistants slowly read the items aloud in a neutral tone, pausing after each item to give students ample time to respond. Students were allotted one, 50-minute class period 
Table 1. Female $(n=373)$ and Male $(n=258)$ Qatari Students' Interest in, and Attitudes Towards, Science (QIAS) - Preparatory School (Grades 7, 8 and 9) Students. Means and Standard Deviations

\begin{tabular}{|c|c|c|c|c|}
\hline \multirow[t]{2}{*}{ Items } & \multicolumn{2}{|c|}{ Females } & \multicolumn{2}{|c|}{ Males } \\
\hline & $M$ & SD & $M$ & SD \\
\hline 1. I enjoy science. & 3.56 & 1.31 & 3.72 & 1.26 \\
\hline 4. I do interesting activities in science classes. & 3.31 & 1.26 & 3.31 & 1.34 \\
\hline 7. Science helps me understand the world around me. & 3.84 & 1.19 & 3.70 & 1.31 \\
\hline 9. I find new developments in science interesting. & 3.74 & 1.31 & 3.74 & 1.35 \\
\hline 10. Science is one of the most interesting school subjects. & 3.29 & 1.30 & 3.39 & 1.44 \\
\hline 11. I enjoy working in the science laboratories of my school & 3.93 & 1.21 & 3.79 & 1.43 \\
\hline 12. I like to watch TV programs about science & 3.40 & 1.33 & 3.45 & 1.37 \\
\hline 13. Science is useful in helping me solve everyday life problems. & 3.53 & 1.25 & 3.53 & 1.33 \\
\hline 15. I will remain interested in science even after I graduate from school. & 3.47 & 1.26 & 3.35 & 1.42 \\
\hline 17. Knowing science can help me make better choices about my health. & 4.00 & 1.14 & 3.79 & 1.29 \\
\hline 20. I hope to specialize in science or a science-related subject. & 3.42 & 1.45 & 3.47 & 1.45 \\
\hline 21. I would like to become a scientist in the future & 3.09 & 1.36 & 3.20 & 1.40 \\
\hline 22. I would enjoy working in a science-related career. & 3.40 & 1.29 & 3.31 & 1.36 \\
\hline 27. I live in a better world because of science. & 3.58 & 1.30 & 3.68 & 1.31 \\
\hline 30. I am confident that I can understand science. & 3.72 & 1.16 & 3.75 & 1.26 \\
\hline 31. I am sure I can do well in science tests. & 3.96 & 1.07 & 4.04 & 1.09 \\
\hline 32. I like science that challenges me. & 3.59 & 1.16 & 3.75 & 1.21 \\
\hline 33. I am confident I will do well in science. & 4.07 & 0.96 & 4.06 & 1.05 \\
\hline 34. I put a lot of effort into learning science. & 3.84 & 1.15 & 3.97 & 1.05 \\
\hline 36. I understand the mathematics used in science. & 3.60 & 1.19 & 3.55 & 1.27 \\
\hline 37. I can explain scientific graphs and tables. & 3.37 & 1.10 & 3.32 & 1.20 \\
\hline 38. I prepare well for science tests. & 4.06 & 1.03 & 4.09 & 1.13 \\
\hline
\end{tabular}

to respond to the items. The actual completion time ranged from 35 to 45 minutes. Also, given that the Qatari population consists of both citizens and non-citizen residents, the items were made available to students in both Modern Standard Arabic and English.

\section{RESULTS}

After a common subset of 22 Likert-items items was administered to all preparatory, secondary, and university students to assess their interest, attitude, and self-efficacy related to science, the data were analyzed using SPSS Statistics software (version 24, 2016). First, the reliability (internal consistency) of the students' responses was assessed. Next, an exploratory factor analysis was used to examine relationships among the items and identify any item subscales. Finally, analyses of variance were used to examine differences among subscale means, and posthoc mean comparisons were made by means of Tukey's Honest Significant Difference (HSD) test. The relative sizes (practical importance) of mean differences were assessed using Hedges' g effect size, interpreting effects as small (0.20 - 0.49), medium (0.50 - 0.79), or large (0.80 and above).

The reliability (internal consistency), assessed by Cronbach's alpha, of the 22 items was .94. According to DeVellis (2012), a Cronbach's alpha above .80 is "very good," .70 to .80 is "respectable," .60 to .69 is "undesirable to minimally acceptable," and below .60 is "unacceptable." The means and standard deviations on the 22 items for female and male students at the preparatory, secondary, and university levels are reported in Tables 1, 2, and 3 . 
Table 2. Female $(n=208)$ and Male $(n=244)$ Qatari Students' Interest in, and Attitudes Towards, Science (QIAS) - Secondary School (Grades 10, 11 and 12) Students. Means and Standard Deviations

\begin{tabular}{|c|c|c|c|c|}
\hline \multirow[t]{2}{*}{ Items } & \multicolumn{2}{|c|}{ Females } & \multicolumn{2}{|c|}{ Males } \\
\hline & $M$ & SD & $M$ & SD \\
\hline 1. I enjoy science. & 3.79 & 1.13 & 3.72 & 1.09 \\
\hline 4. I do interesting activities in science classes. & 3.33 & 1.19 & 3.08 & 1.18 \\
\hline 7. Science helps me understand the world around me. & 3.92 & 1.04 & 3.79 & 1.09 \\
\hline 9. I find new developments in science interesting. & 3.88 & 1.13 & 3.80 & 1.23 \\
\hline 10. Science is one of the most interesting school subjects. & 3.36 & 1.30 & 3.45 & 1.22 \\
\hline 11. I enjoy working in the science laboratories of my school & 3.88 & 1.17 & 3.55 & 1.34 \\
\hline 12. I like to watch TV programs about science & 3.53 & 1.22 & 3.39 & 1.31 \\
\hline 13. Science is useful in helping me solve everyday life problems. & 3.55 & 1.18 & 3.37 & 1.22 \\
\hline 15. I will remain interested in science even after I graduate from school. & 3.68 & 1.14 & 3.55 & 1.22 \\
\hline 17. Knowing science can help me make better choices about my health. & 4.12 & 0.98 & 3.76 & 1.11 \\
\hline 20. I hope to specialize in science or a science-related subject. & 3.82 & 1.27 & 3.76 & 1.33 \\
\hline 21. I would like to become a scientist in the future & 3.25 & 1.29 & 3.18 & 1.26 \\
\hline 22. I would enjoy working in a science-related career. & 3.77 & 1.20 & 3.56 & 1.21 \\
\hline 27. I live in a better world because of science. & 4.00 & 1.04 & 4.05 & 1.11 \\
\hline 30. I am confident that I can understand science. & 3.88 & 0.95 & 3.91 & 1.05 \\
\hline 31. I am sure I can do well in science tests. & 3.98 & 0.99 & 4.05 & 0.99 \\
\hline 32. I like science that challenges me. & 3.76 & 1.08 & 3.61 & 1.09 \\
\hline 33. I am confident I will do well in science. & 3.98 & 0.93 & 3.97 & 0.98 \\
\hline 34. I put a lot of effort into learning science. & 3.90 & 1.06 & 3.75 & 0.99 \\
\hline 36. I understand the mathematics used in science. & 3.84 & 1.03 & 3.88 & 0.98 \\
\hline 37. I can explain scientific graphs and tables. & 3.41 & 1.01 & 3.34 & 1.15 \\
\hline 38. I prepare well for science tests. & 4.14 & 0.90 & 3.89 & 0.99 \\
\hline
\end{tabular}

Table 3. Female $(n=498)$ and Male $(n=254)$ Qatari Students' Interest in, and Attitudes Towards, Science (QIAS) - University Students. Means and Standard Deviations

\begin{tabular}{|c|c|c|c|c|}
\hline \multirow[t]{2}{*}{ Items } & \multicolumn{2}{|c|}{ Females } & \multicolumn{2}{|c|}{ Males } \\
\hline & $M$ & $S D$ & $M$ & $S D$ \\
\hline 1. I enjoy science. & 3.54 & 1.15 & 3.67 & 1.11 \\
\hline 4. I do interesting activities in science classes. & 3.10 & 1.11 & 3.32 & 1.08 \\
\hline 7. Science helps me understand the world around me. & 3.63 & 1.11 & 3.63 & 1.13 \\
\hline 9. I find new developments in science interesting. & 3.73 & 1.04 & 3.86 & 1.00 \\
\hline 10. Science is one of the most interesting school subjects. & 3.55 & 1.00 & 3.67 & 1.09 \\
\hline 11. I enjoy working in the science laboratories of my school & 3.41 & 1.10 & 3.60 & 1.11 \\
\hline 12. I like to watch TV programs about science & 3.35 & 1.14 & 3.62 & 1.08 \\
\hline 13. Science is useful in helping me solve everyday life problems. & 3.47 & 1.07 & 3.77 & 0.97 \\
\hline 15. I will remain interested in science even after I graduate from school. & 3.40 & 1.13 & 3.55 & 1.07 \\
\hline 17. Knowing science can help me make better choices about my health. & 3.82 & 1.00 & 3.75 & 1.01 \\
\hline 20. I hope to specialize in science or a science-related subject. & 3.37 & 1.26 & 3.57 & 1.20 \\
\hline 21. I would like to become a scientist in the future & 3.11 & 1.20 & 3.33 & 1.12 \\
\hline 22. I would enjoy working in a science-related career. & 3.38 & 1.11 & 3.58 & 1.09 \\
\hline 27. I live in a better world because of science. & 3.77 & 1.07 & 3.86 & 1.00 \\
\hline 30. I am confident that I can understand science. & 3.63 & 1.04 & 3.81 & 1.02 \\
\hline 31. I am sure I can do well in science tests. & 3.64 & 1.02 & 3.83 & 0.96 \\
\hline 32. I like science that challenges me. & 3.54 & 1.05 & 3.71 & 1.10 \\
\hline 33. I am confident I will do well in science. & 3.42 & 1.07 & 3.61 & 1.04 \\
\hline 34. I put a lot of effort into learning science. & 3.50 & 1.08 & 3.58 & 1.07 \\
\hline 36. I understand the mathematics used in science. & 3.56 & 1.05 & 3.78 & 1.10 \\
\hline 37. I can explain scientific graphs and tables. & 3.41 & 1.03 & 3.63 & 0.99 \\
\hline 38. I prepare well for science tests. & 3.62 & 1.07 & 3.76 & 0.98 \\
\hline
\end{tabular}

The percentages of female and male students at the preparatory, secondary, and university levels who would like to become scientists in the future are in Table 4. The Qatari students include both citizens and non-citizen residents. These percentages were determined by adding together the percentages of students who "strongly agree" or "agree" with Item 21, "I would like to become a scientist in the future." As can be seen in Table 4, about 41 percent of Qatari students would like to be scientists. Citizenship plays a role in the decision. A greater percentage 
Table 4. The percentages of Qatari and non-Qatari female and male students at the preparatory, secondary, and university levels who would like to become a scientist in the future

\begin{tabular}{lccccc}
\hline & \multicolumn{2}{c}{ Citizens } & \multicolumn{2}{c}{ Residents } & Males \\
\hline & Females & Males & Females & 52.85 & 41.03 \\
\hline Preparatory & 24.79 & 33.83 & 46.96 & 42.70 & 43.68 \\
\hline University & 42.10 & 33.33 & 49.30 & 45.31 & 38.78 \\
\hline Total & 33.67 & 35.71 & 40.91 & 46.20 & 40.74 \\
\hline
\end{tabular}

Note. These percentages are based on the students who responded "strongly agree" or "agree" to the item "I would like to become a scientist in the future." Qatari students include both Qatari citizens and non-citizen residents

of non-citizen residents want to be scientists than citizens. With respect to gender, the most notable differences were among female citizens, who had less interest in a science career in preparatory school, more in secondary school, and then less again in the university.

An exploratory factor analysis conducted with SPSS was used to examine relationships among the 22 items (observed variables) and identify those sets of items (latent variables or "factors") that have common characteristics. An exploratory factor analysis, rather than a confirmatory factor analysis, was appropriate in this situation because the 22 items had not be administered as a set before, some were improved, and the relationships between the observed and latent variables were uncertain.

The exploratory factor analysis steps recommended by Thompson (2004) were carried out to assess the adequacy of the matrix of correlations among the items, extract the factors, rotate them, examine the factor loadings, and interpret the factors. The sample size $(n=1,799)$ met Comrey and Lee's (1992) exploratory factor analysis criterion: A sample of more than 500 cases is "very good." Correlations for all pair-wise combinations of the 22 items were calculated. The resulting matrix of correlations was shown to be appropriate for factor analysis by means of a Bartlett's test of sphericity.

A principal component analysis was performed on the items. A principal component analysis uses eigenvalues, which represent the proportion of variance accounted for by the factors. Eigenvalues are used to derive factor loadings, which indicate how strongly particular items are related to particular factors.

Using the Kaiser-Guttman rule, two factors were identified that had eigenvalues greater than 1, indicating that they accounted for significant amounts of the total variance in the items. The eigenvalue and percent of variance explained by each factor were: factor $1(10.36,47.11 \%)$ and factor $2(1.55,7.06 \%)$.

Together, these two factors accounted for $54.17 \%$ of that variance, which is more than satisfactory. A scree plot was then examined, with potential factors plotted against their eigenvalues in descending order of magnitude to identify breaks in the slope of this plot. The scree plot supported the 2-factor solution obtained using the KaiserGuttman rule.

The factors were rotated, turning their reference axes about their origin. Rotation is needed routinely because the original factor structure, while mathematically accurate, is difficult to interpret. A Varimax rotation was used to produce a simple structure that facilitates interpretation; a Direct Oblimin rotation was also used with similar results.

The factor loadings from the principal components analysis with the Varimax solution are in Table 5. This table show the 15 items that met the criteria for including them in the factor. The criteria were a factor loading of at least .6 on one factor and no more than .4 on the other factor (Tabachnick \& Fidell, 2000). The 7 items (of the original 22) that did not meet the criteria were excluded. 
Table 5. Exploratory factor analysis of interest, attitude, and self-efficacy items

\begin{tabular}{lll}
\hline & & Factor \\
\hline & & $\mathbf{2}$ \\
\hline Factor 1: Science Affect & & \\
\hline 22. I would enjoy working in a science-related career. & .769 & .271 \\
\hline 15. I will remain interested in science even after I graduate from school. & .753 & .321 \\
\hline 9. I find new developments in science interesting. & .738 & .276 \\
\hline 13. Science is useful in helping me solve everyday life problems. & .729 & .173 \\
\hline 7. Science helps me understand the world around me. & .726 & .269 \\
\hline 27. I live in a better world because of science. & .722 & .273 \\
\hline 17. Knowing science can help me make better choices about my health. & .674 & .337 \\
\hline 12. I like to watch TV programs about science. & .672 & .165 \\
\hline 20. I hope to specialize in science or a science-related subject. & .645 & .317 \\
\hline 10. Science is one of the most interesting school subjects. & .617 & .388 \\
\hline Factor 2: Science Self-Efficacy & & .789 \\
\hline 36. I understand the mathematics that is used in science. & .262 & .736 \\
\hline 33. I am confident I will do well in science. & .226 & .721 \\
\hline 31. I am sure I can do well in science tests. & .221 & .636 \\
\hline 38. I prepare well for science tests. & .209 & .167 \\
\hline 34. I put a lot of effort into learning science. & & \\
\hline
\end{tabular}

Having identified two factors, one with 10 items and one with 5, each of which accounted for a meaningful amount of variance in students' responses, the next step was to generate composite scores to represent values for the factors. There are two approaches to generating such composite scores: factor-based scales and estimated factor scores. The former was chosen for reasons explained by Pett et al. (2003, p. 223): “An advantage to using a factorbased scale approach to generating factor scores is that these scores are more easily interpreted than estimated factor scores and can also be compared from one study to another. The correlations between estimated factor scores and factor-based scales are also high."

Factor 1 was called science interest and attitude and factor 2 was called self-efficacy. The students responded to the interest and attitude items similarly, implying that interest and attitude are highly related, and so these items are in one factor. Both interest and attitude have an emotional (feeling) aspect, and it is reasonable that they are interconnected. Self-efficacy, in comparison, is a belief. The reliability, assessed by Cronbach's alpha, of the 10 interest and attitude items was .92; the reliability of the 5 self-efficacy items was .82 .

A 2 (gender) x 3 (school level) analysis of variance was conducted to examine differences in students' factor 1 (interest and attitude) scores due to gender (females and males) and school level (preparatory, secondary, and university). The possible scale scores ranged from 10 to 50 . There was no statistically significant difference found between the scores of females and males. There was a significant difference among school levels, $p<.05(\mathrm{~F}=3.69$, MSe $=78.28)$. Secondary students $(M=37.00)$ scored higher than preparatory students $(M=35.68)$ and university students $(\mathrm{M}=35.95)$. These differences, while statistically significant, are small. The interaction of gender and school level was not significant.

Similarly, a 2 (gender) $\times 3$ (school level) analysis of variance was also conducted to examine differences in students' factor 2 (self-efficacy) scores due to gender (females and males) and school level (preparatory, secondary, and university). The possible scale scores ranged from 5 to 25 . There was no statistically significant difference found between the scores of females and males. There was a significant difference among school levels, $p<.001(\mathrm{~F}=28.38$, MSe $=78.290)$. Preparatory students $(M=19.60)$ and secondary students $(M=19.67)$ scored similarly and both had higher scores than university students $(M=18.06)$. The difference, while statistically significant, were small. The interaction of gender and school level was not significant.

\section{DISCUSSION}

In the present study, a large sample of Qatari female and male students at the preparatory, secondary, and university levels responded to a set of Likert items about their interest, attitude, and self-efficacy in the area of science. The items were similar to those used in TIMSS and PISA but improved upon them in several ways, consistent with item guidelines in the affective domain.

The means of students' responses indicated that students tended to respond slightly positively to items about their interest (e.g., Science is one of the most interesting school subjects), attitude (e.g., I like to watch TV programs about science.), and self-efficacy (e.g., I am confident I will do well in science). The standard deviations of the means indicated that about two-thirds of the students responded within one scale point above and below the mean. 
The lack of a neutral point on TIMSS and PISA 4-point response scales forces students to pick a positive or negative option. In theory, the lack of a neutral point could increase mean positive response, increase mean negative response, or have no effect on mean response. In the case of Qatari students, their mean positive response was more positive when the response scale lacked a neutral point. Using a response scale without a neutral point reduces the accuracy of items because the responses may not be truly representative of what the students think. In reality, some students, particularly young ones, may be genuinely uncertain about their interest, attitude, or self-efficacy.

When responding to TIMSS and PISA, the lack of a neutral point may have increased the tendency of Qatari students to select a positive response, perhaps because they believed that is what their test administrators and instructors wanted. A direction for future research is to use qualitative methods such as interviewing to gain insight into how students, who are uncertain, chose a response when no neutral point exists. The present findings have implications for all countries that use TIMSS and PISA because the use of forced-choice items with children may yield misleading findings.

Qatari students in the present study tended to be positive in their interest, attitude, and self-efficacy responses, just not as positive as TIMSS and PISA reported. The present findings imply that TIMSS and PISA overestimated how positive the Qatari students are. Both the present findings and those of TIMSS and PISA raise an important question: If the students' interest, attitude, and self-efficacy are positive, then why do the students have such relatively low achievement scores on TIMSS and PISA? The answer may be the instructional methods and conditions of Qatar's developing educational system (Abd-El-Khalick et al., 2015; Said, 2016; Said, Summers, AbdEl-Khalick, \& Wang, 2016).

The quality, consistency, and the rigor of the instructional methods used to teach science in Qatar may not be as high as those of countries such as Singapore, Japan, Chinese Taipai (Taiwan), and Korea that score at the top internationally. Also, the variability in the kinds of schools in Qatar, public and private, and the large class sizes in many Qatari schools could contribute to lower achievement scores. A direction for future research is to evaluate the influence of instructional methods and conditions on Qatari students' science achievement scores on international tests.

The present findings and those of TIMSS and PISA raise another important question. How can Qatari students (or the students of any country) be relatively high in interest, attitude, and self-efficacy, yet low in science achievement? First, it is important to distinguish between individual data and country data. TIMSS and PISA have found that individual interest, attitude, and self-efficacy of students within a country are positively related to achievement. But when the data of countries are compared, TIMSS and PISA have routinely found a paradox: a negative relationship (Mullis, Martin, \& Loveless, 2016).

Many low-achieving countries (like Qatar) have a higher percentage of students who like science than many high-achieving countries (like Korea and Japan). For example, in the eighth grade, TIMSS 2015 found that $38 \%$ of Qatari students "very much like science," but only 15\% of Japanese and 10\% of Korean students do. The same paradox, which involves Asian countries, has appeared in every TIMSS and PISA cycle for affective domain items. There are at least three possible explanations. One explanation is that Asian countries encourage students to be humble and modest to a greater degree than other countries. Another is that the high cultural expectations in Asian countries for student achievement in science have caused many students to dislike science and question their capability. Yet another explanation is that in high achieving countries, students' may be preoccupied with competition and, as a result, become depressed about learning science. There is no agreement yet on what is the best explanation for the paradox.

Another purpose of the present student was to assess the intent of Qatari students to pursue careers in science. About 41 percent of Qatari students reported they would like to be scientists. The percentage increases to about $45 \%$ when the item is worded "a science-related career." Citizenship is related to students' decision to pursue a career in science or a science-related career. Non-citizen residents are much more likely than citizens to express interest in science careers. In Qatar, as in many developing countries with expanding economies, parents who are non-citizen residents have high expectations for their children to work hard and succeed in traditionally valued careers such as science (OECD, 2015). Sometimes non-citizen residents have higher expectations than citizens do. That is not to say that the Qatari students who are citizens, or their parents, do not have high career expectations: they do, but university data suggest that those expectations are shifting to careers in finance, away from science.

Regarding gender and interest in a science career (reviewed by Wiebe, Unfried, \& Faber, 2018), the present findings indicated that science career interest was particularly low among female citizens in the preparatory schools. Less encouragement of girls to be scientists is likely a traditional aspect of Qatari culture, but by secondary school girls want to be scientists more than boys do. Zahidi (2018), in her book Fifty Million Rising, documented that young women in Arab countries are increasingly pursuing careers in science. While some Arab cultures are associated with strict social codes for men and women, gender stereotypes about work are becoming less pervasive, and women are increasingly entering the science workforce. 
Zahidi (2018) notes that women in Arab countries still face many of the same obstacles as their counterparts elsewhere, like finding childcare or delegating household work. But, Zahidi says, they are persevering despite the barriers and making breakthroughs that benefit those who follow them. Also relevant to gender and interest in a science career in Qatar, Sellami et al. (2017, p. 6491) conclude: "Girls are more attracted to STEM careers, whereas boys tend to be drawn to occupations in the public sector."

In conclusion, Qatari students' interest, attitude, and self-efficacy in the area of science contribute to their scientific literacy and can increase the likelihood that they will pursue careers in science or science-related areas. The scientific literacy of students is important worldwide. The present findings have implications for all countries that use TIMSS and PISA, particularly those countries with developing educational systems, rapidly expanding economies, and an increasing need for students in science careers.

\section{ACKNOWLEDGEMENTS}

The NPRP 8-503-5-065 team members would like to thank the Qatar National Research Fund for the generous support of this research through the National Priority Research Program. Any opinions, findings, conclusions or recommendations expressed in this report are those of the PIs and do not necessarily reflect the views of the Qatar National Research Fund; QNRF has not approved or endorsed its content. We would also like to thank the many students, teachers, administrators, and staff who made this study possible. We deeply appreciate their contributions and professionalism.

\section{REFERENCES}

Abd-El-Khalick, F., Summers, R., Said, Z., Wang, S., \& Culbertson, M. (2015) Development and large-scale validation of an instrument to assess Arabic-speaking students' attitudes toward Science. International Journal of Science Education, 37(16), 2637-2663. https:/ / doi.org/10.1080/09500693.2015.1098789

Allen, E., \& Seaman, C. (2007). Likert scales and data analyses. Quality Progress, 64-65. Retrieved from http:/ / asq.org/quality-progress/2007/07/statistics/likert-scales-and-data-analyses.html

Comrey, A., \& Lee, H. (1992). A first course in factor analysis. Hillsdale, NJ: Erlbaum.

DeVellis, R. F. (2012). Scale development: Theory and applications (3rd ed.). Los Angeles: Sage.

Feinstein, N. (2011). Salvaging science literacy. Science Education, 95, 168-185. https://doi.org/10.1002/ sce.20414

Fortus, D. (2014). Editorial: attending to affect. Journal of Research in Science Teaching, 51, 821-835. https://doi.org/10.1002/tea.21155

Kelly, G. J. (2011). Scientific literacy, discourse, and epistemic practices. In C. Linder, L. Martin, M. O., Mullis, I. V. S., Foy, P., \& Hooper, M. (2016). TIMSS 2015 International results in science. Retrieved from Boston College, TIMSS \& PIRLS International Study Center website: http:/ / timssandpirls.bc.edu/timss2015/internationalresults/

Miller, M. D., Linn, R. L., \& Gronlund, N. E. (2013). Measurement and assessment in teaching (11 ${ }^{\text {th }}$ ed.). Boston: Pearson.

Mullis, I. V.S., Martin, M. O., \& Loveless, T. (2016). 20 Years of TIMSS: International Trends in Mathematics and Science Achievement, Curriculum, and Instruction. Chestnut Hill, MA: TIMSS \& PIRLS International Study Center, Boston College. Retrieved from http:/ / timss2015.org/timss2015/wp-content/ uploads/2016/T15-20-yearsof-TIMSS.pdf

Nowlis, S. M., Kahn, B. E., \& Dhar, R. (2002). Coping with ambivalence: The effect of removing a neutral option on consumer attitude and preference judgments. Journal of Consumer Research, 29, 319-334. https://doi.org/10.1086/344431

OECD. (2015). Helping immigrant students to succeed at school-and beyond. Retrieved from https:/ / www.oecd.org/education/Helping-immigrant-students-to-succeed-at-school-and-beyond.pdf

OECD. (2016a). PISA 2015 Assessment and analytical framework: Science, reading, mathematic and financial Literacy, PISA, Paris: OECD Publishing. Retrieved from https://www.mecd.gob.es/dctm/inee/internacional/pisa-2015frameworks.pdf?documentId=0901e72b820fee48

OECD. (2016b). PISA 2015 Results in focus. Retrieved from https://www.oecd.org/pisa/pisa-2015-results-infocus.pdf

OECD. (2018a) Education GPS. Retrieved from http:/ / gpseducation.oecd.org

OECD. (2018b). Country profile, Qatar. Retrieved from http://gpseducation.oecd.org/CountryProfile? primaryCountry $=$ QAT\&treshold $=10 \&$ topic $=$ PI 
Osborne, J. F., Simon, S., \& Collins, S. (2003). Attitudes towards science: A review of the literature and its implications. International Journal of Science Education, 25, 1049-1079. https:/ / doi.org/10.1080/0950069032000032199

Ostman, D. A. Roberts, P. Wickman, G. Erikson, \& A. McKinnon (Eds.). (2010). Exploring the landscape of scientific literacy (pp. 61-73). New York: Routledge.

Pett, M. A., Lackey, N. R., \& Sullivan, J. J. (2003). Making sense of factor analysis: The use of factor analysis for instrument development in health care research. London: Sage Publications. https://doi.org/10.4135/9781412984898

Popham, W. J. (2014). Classroom assessment (7th ed.). Boston: Pearson.

Qatar Ministry of Development Planning and Statistics (2018). Retrieved from https://www.mdps.gov.qa/en/aboutus1/Pages/default.aspx

Qatar Ministry of Development Planning and Statistics. (2017). Education in Qatar statistical profile 2016. Retrieved from https://www.mdps.gov.qa/en/statistics/Statistical\%20Releases/Social/Education/2016/Education _Statistical_Pro\%EF\%AC\%81le_2016_En.pdf

Said, Z. (2016). Science education reform in Qatar: Progress and challenges. Eurasia Journal of Mathematics, Science $\mathcal{E}$ Technology Education, 12(8), 2253-2265. https:/ / doi.org/10.12973/eurasia.2016.1301a

Said, Z., Summers, R., Abd-El-Khalick, F., \& Wang. S. (2016) Attitudes toward science among grades 3 through 12 Arab students in Qatar: Findings from a cross-sectional national study. International Journal of Science Education, 38(4), 621-643. https:/ / doi.org/10.1080/09500693.2016.1156184

Sellami, A., Kimmel, L., Wittrock, J., Hunscher, B., Cotter, A., Al-Emadi, A. \& Al-Emadi, D. (2017). Factors shaping Qatari students' career expectations in STEM, business or public sector fields. Eurasia Journal of Mathematics, Science, and Technology Education, 13, 6491-6505. Retrieved from http:/ / www.ejmste.com/Factors-ShapingQatari-Students-Career-Expectations-in-STEM-Business-or-Public-Sector,77043,0,2.html https://doi.org/10.12973/ejmste/77043

Sheldrake, R., Mujtaba, T., \& Reiss, M. J. (2017). Science teaching and students' attitudes and aspirations: The importance of conveying the applications and relevance of science. International Journal of Science Education, 85, 167-183. https://doi.org/10.1016/j.ijer.2017.08.002

Tabachnick, B. G., \& Fidell, L. (2000). Using multivariate statistics (4th ed.). Boston: Allyn \& Bacon.

Wiebe, E., Unfried, A., \& Faber, M. (2018). The relationship of STEM attitudes and career interest. Eurasia Journal of Mathematics, Science E Technology Education, 14(10), 2-17. https:/ / doi.org/10.29333/ ejmste/92286

Zahidi, S. (2018). Fifty million rising: The new generation of working women transforming the Muslim world. New York: Nation Books.

\section{http://www.ejmste.com}

